\title{
Chemiluminescence Methods (Present and Future)
}

\author{
By A.M. Jimenez* and M.J. Navas \\ Departamento de Química Analítica. Facultad de Farmacia. Universidad de Sevilla. \\ c/Prof. García González, s/n. 41012-Sevilla (España) \\ e-mail:jimenez@fafar.us.es
}

\section{CONTENTS}

1. Introduction

2. Chemiluminescence reactions

2.1. Chemiluminescence reaction with luminol

2.2. Chemiluminescence reaction with $\mathrm{Ce}(\mathrm{IV})$

2.3. Chemiluminescence reaction with $\mathrm{KMnO}_{4}$

2.4. Chemiluminescence reaction with tris (2,2'-bipyridyl) ruthenium (III)

3. Antioxidant activity and radical scavenging

4. Chemiluminescence and olive oil

5. Analyte seawater determination by chemiluminescence

6. Chemiluminescence in pharmaceutical samples

7. Conclusions

References

\section{RESUMEN}

Métodos de quimiluminiscencia (presente y futuro).

Este artículo da una visión general de los métodos de quimiluminiscencia en algunas de las aplicaciones más recientes en análisis de drogas, análisis del agua marina o la actividad antioxidante de productos naturales y de síntesis (incluyendo el aceite de oliva). Las consideraciones prácticas no están incluidas ya que el principal interés es establecer, a través de las aplicaciones mencionadas, que la quimiluminiscencia ha sido, es y será en los próximos años una herramienta versátil de la Química Analítica.

PALABRAS-CLAVE: Actividad antioxidante - Análisis de agua marina - Análisis de drogas - Quimiluminiscencia.

\section{SUMMARY}

\section{Chemiluminescence methods (present and future).}

This article provides a general review of chemiluminescent methods in some of their recent applications in drug analysis, sea water analysis or antioxidant activity of natural and synthetic products (including olive oil). Practical considerations are not included in the review since the main interest is to state, through the aforementioned applications, that chemiluminescence has been, is, and will be a versatile tool for Analytical Chemistry in future years.

KEY-WORDS: Antioxidant activity - Chemiluminescence - Drug analysis - Radical scavenging - Seawater analysis.

\section{INTRODUCTION}

We can define the term chemiluminescence $(C L)$ as the emission of ultraviolet, visible or infra-red radiation from a molecule or atom as the result of the transition of an electronically excited state, having been produced as a consequence of a chemical reaction. This chemical reaction produces energy in sufficient amount to induce the transition of an electron from its ground state to an excited electronic state. This electronic transition is often accompanied by vibrational and rotational changes in the molecule. In organic molecules, transitions from a $\pi$ bonding to a $\pi^{*}$ anti-bonding orbital $\left(\pi \rightarrow \pi^{*}\right)$ or from a non-bonding to an anti-bonding orbital $\left(\mathrm{n} \rightarrow \pi^{*}\right)$ are most frequently encountered. (Dodeigne et al., 2000). When the reaction occurs in a living system or it is derived from one, the process is called bioluminescence $(\mathrm{BL})$.

Luminescent reactions has been observed since ancient time, luminous animals are known in the Greek civilisation, however the first report of artificial chemiluminescence occurred in 1669. The German physician Henning Brand isolated from urine a substance that glowed continuously in the dark. He called the substance "phosphorus mirabilis", and it is better known today as white phosphorus (Barnett and Lewis, 1996). In the $19^{\text {th }}$ century it was found that rather simple organic compounds could also give rise to chemiluminescence. Radziszewski observed the green light emission when oxygen was bubbled into an alkaline ethanolic solution of 2,4,5-triphenylimidazole (lophine) (Isacsson and Wettermark, 1974). This discovery was published in the year 1877 . The term chemiluminescence was first coined in 1888 by Eilhardt Weidemann, as a part of his classification of "cold light" (luminescence). Forty years later, Albrecht in 1928 reported the luminescent properties of 5-amino-2,3-dihydrophtalazine-1,4-dione (luminol). Early research on CL was mainly focused on the observation of a reaction and investigation of the mechanism and the analytical applications of the phenomenon appeared in the literature in 1960s (Palilis and Calokerinos, 2000).

Nowadays, a lot of inorganic and organic CL reaction are known. A typical CL reaction would be (Townshend, 1990):

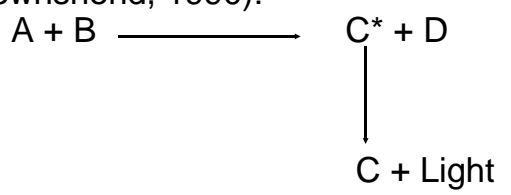

where $\left({ }^{*}\right)$ indicates an electronically excited state. Sometimes, The excited product $\left(C^{*}\right)$ is an ineffective emitter, but it can transfer the excitation energy to an efficient fluorophore $(F)$ added to the system: 


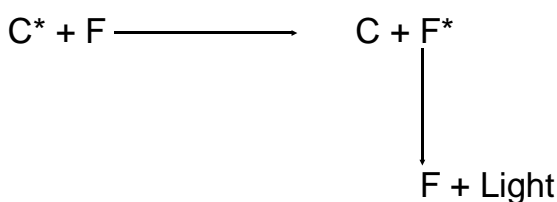

Now, the emission is identical with the fluorescence of $\mathrm{F}$ and we can classify that as indirect, sensitised, or energy transfer chemiluminescence.

The light emission generated from a chemical reaction requires no light source for excitation, the analytical signal appears out of an essentially black background, and the only background signal is that of the photomultiplier tube's dark current. Analytically, the $C L$ reactions are attractive due to: (a) Excellent sensibility and excellent detection limits because there is absence of source noise and scatter. (b) Sometimes high selectivity due to the limited number of available reactions. (c) Simple, robust and inexpensive instrumentation (Schmidt, 1999) suitable to both batch and flow analytical techniques. Furthermore, the introduction of flow injection analysis has made CL methods even more attractive because it is possible to mix sample and reagent rapidly with high reproducibility.

Chemiluminogenic reactions mainly occur in solution and in the gas phase. The most common or well known solution phase systems involve luminol (or its derivatives), oxalate esters, lucigenin (N,N'-dimethyl-9-9'-diacridinium nitrate) or its derivatives, ruthenium tris-bipyridine and luciferin. Gas phase examples include the ozone- and fluorine- induced, sodium vapor, and chlorine dioxide chemiluminescence detectors for gas chromatography (Van Fleet-Stalder and Chasteen).

The CL techniques have been applied to a great variety of analytes and samples. In literature we can

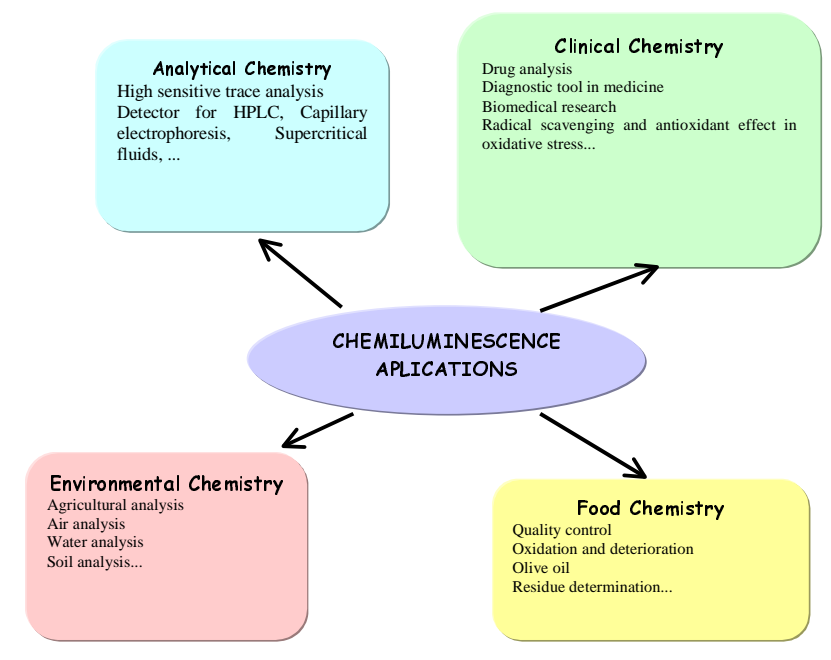

Figure 1

Some possible applications of CL methods. find several dedicated reviews which show the importance of this techniques in some interesting fields as clinical (Kricka, 1994, Roda et al., 2000), food (Navas and Jiménez, 1996), environmental (Jiménez and Navas, 1997; Navas et al., 1997) or analytical chemistry (Huang and Fang, 2000; Jiménez and Navas, 1999; Palilis and Calokerinos, 2000). In the figure 1 we have summarised the most important applications of CL methods in several fields. Currently, it is possible to consider the $\mathrm{CL}$ methods as a powerful tools in Analytical Chemistry.

Today, the great variety of $C L$ applications that have appeared in literature makes an exhaustive revision of them very difficult. In this review we have selected and summarised some interesting applications of $C L$ techniques such as drug analysis, sea water analysis or antioxidant activity of natural and synthetic products, with the aim of giving an overview of the possibilities of these methods in some aspects of the environmental, clinical and food fields as olive oil. The selected bibliography is a small sample of the numerous reports appeared in the recent years since we have only tried to reflect the current tendency towards the CL techniques in these fields. Previously, the reagents and reactions which are the basis of the CL methods applied in the most described cases are briefly summarised.

\section{CHEMILUMINESCENCE REACTIONS}

\subsection{Chemiluminescence reaction with luminol}

In aqueous solutions, the most commonly used chemiluminescent species is luminol. The chemiluminescence of luminol (5-amino-2,3dihydrophthalazine-1,4-dione) was first described by Albrecht in 1928. This compound reacts with a potent oxidizing agent (e.g. $\mathrm{H}_{2} \mathrm{O}_{2}$ ) in the presence of a catalyst (generally a metal or metal-containing compound or a enzyme) in alkaline solution to yield 3-aminophthalate in an excited electronic state which returns to ground state with the production of light.

The most obvious use of the reaction has been to determine oxidants or compounds which interact with oxidant, but it is possible to determine metal ions by their catalysis of the CL reaction or products of enzyme-catalyzed reactions.

\subsection{Chemiluminescence reaction with $\mathrm{Ce}$ (IV)}

According to the investigation of $\mathrm{CL}$ properties of the fluorophore-sensitized $\mathrm{Ce}$ (IV) reaction system by Zhang et al. (1995), a possible CL mechanism of the reaction may be attributed to the following reactions:

$$
\begin{gathered}
\mathrm{Ce}(\mathrm{IV})+\text { analyte }(\text { red }) \\
\mathrm{Ce}(\mathrm{III})^{*} \rightarrow \mathrm{Ce}(\mathrm{III})^{\star}+\text { analyte (ox) } \\
\mathrm{Ce}(\mathrm{III})+\text { light }
\end{gathered}
$$

and/or $\mathrm{Ce}(\mathrm{III})$-analyte complex ${ }^{*} \rightarrow \mathrm{Ce}(\mathrm{III})+$ analyte + light 
In the presence of a fluorophore, $\mathrm{Ce}$ (III) ions or the $\mathrm{Ce}(\mathrm{III})$-analyte complex transfer the excess energy to the fluorophore which in turn generates CL emission:

$$
\begin{aligned}
& \mathrm{Ce}(\mathrm{III})^{*}+\text { fluorophore } \rightarrow \mathrm{Ce}(\mathrm{III})+\text { fluorophore }^{*} \\
& \text { and/or } \mathrm{Ce}(\mathrm{III}) \text {-analyte complex* + fluorophore } \rightarrow \mathrm{Ce}(\mathrm{III}) \\
& + \text { analyte + fluorophore* } \\
& \text { fluorophore }^{*} \rightarrow \text { fluorophore + light }
\end{aligned}
$$

\subsection{Chemiluminescence reaction with $\mathrm{KMnO}_{4}$}

A possible CL mechanism proposed by Aly et al. (1998) may be attributed to the following reactions:

analyte $+\mathrm{MnO}_{4}^{-}+8 \mathrm{H}^{+} \rightarrow$ Oxidized analyte ${ }^{*}+\mathrm{Mn}^{++}+4 \mathrm{H}_{2} \mathrm{O}$

In the presence of a fluorophore, the energy resulting from the redox reaction can be effectively transferred to quinine which in turn generates CL emission.

$$
\begin{aligned}
& \begin{array}{c}
\text { Oxidized analyte } \\
\text { fluorophore }
\end{array} \vec{*} \text { Oxidized analyte + } \\
& \text { fluorophore }^{*} \rightarrow \text { fluorophore }+ \text { light }
\end{aligned}
$$

\subsection{Chemiluminescence reaction with tris (2,2'-bipyridyl)ruthenium (III)}

Since the initial discovery of $R u(\text { bipy })_{3}{ }^{2+}$ chemiluminescence, its utility has been applied to the production of reactive oxidant, $\mathrm{Ru}(\mathrm{bipy}) \mathrm{3}_{3}{ }^{3+}$, followed by reduction, by an analyte species, to produce an emission of light (Aly et al., 2000 b):

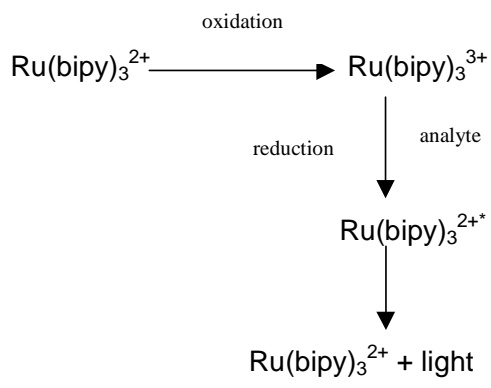

Gerardi et al., 1999 summarises some mechanistic considerations of the $\mathrm{CL}$ reaction proposed by some authors.

\section{ANTIOXIDANT ACTIVITY AND RADICAL SCAVENGING}

The interest in scientific literature towards products which exhibiting a protective function in the oxidative changes which take place in foods (mainly, in relation to the production of reactive oxygen species) has been increasing in recent years, as reflected in the numerous reviews focussing on this topic (Robards and Antolovich, 1997, Robards et al., 1999, Prior and Guohua, 2000). Oxidative changes in foods are important in terms of nutritional quality, flavor, odor, spoilage, and potential toxicity resulting from ingestion of oxidation reaction products (Yasaei et al., 1996). The term antioxidants in food is applied to those compounds which act interrupting the chain of free radicals (primary antioxidants), consuming oxygen or discomposing hydroperoxides into stable products (secondary antioxidants), (Kochlahr and Rosell cited by Galeano Diaz, 1996), or anyway act as enzymatic antioxidants or chelating agent.

On the other hand, oxidative stress is increasingly becoming an important hypothesis to explain the genesis of several pathologies, including cancer, atherosclerosis, aging (Blache et al. 1999) or Alzheimer's disease (Mclntosh et al. 1997, Smith et al. 2000). Dietary factors (among others) are known to be involved in the production of reactive oxygen species which play important roles in oxidative stress, but on the other hand, protective functions of several components of foods and natural products (Phenolic compounds, vitamins...), in the aforementioned pathologies, seem to be largely due to their ability for scavenging reactive oxygen species.

In living systems, dietary antioxidants ( $\alpha$-tocopherol, $\beta$-carotene, ascorbic acid) and endogenous enzymes protect against oxidative damage (Moure et al., 2001). Enzymes such as superoxide dismutase (catalyze the dismutation of the superoxide radical to $\mathrm{H}_{2} \mathrm{O}_{2}$ and molecular oxygen) or catalase (catalyzes the breakdown of toxic $\mathrm{H}_{2} \mathrm{O}_{2}$ to water, preventing the secondary generation of hydroxyl radical) are involved in these defensive processes. Therefore, antioxidants are species which could play an important role in the protection from damage produced by oxidative processes that take place in our body.

In this section we have tried to compile some of the most recent reports on the possibilities of chemiluminescence methods as a reliable tool for detection and evaluation of the antioxidative activity of a great deal of natural and synthetic products, which work by mechanisms mentioned above. The growing interest in studying the antioxidant properties of some components of natural products is directly related to their protective function in foods and in human health, therefore papers reviewed here are focused in both directions.

At the same time, the summarized literature shows how CL methods have been widely applied as sensitive assay for detection and measurement of reactive oxygen species involved in the oxidative processes.

Oxygen-derived free radicals such as singlet molecular oxygen (SMO) $\left({ }^{1} \mathrm{O}_{2}\right)$, superoxide anion radical (SAR) $\left(\mathrm{O}_{2}^{-}\right)$and hydroxyl radical (HR) $(\cdot \mathrm{OH})$ are a very high reactive species. The identification of radical species is not easy due to their short lifetimes and different chemical properties. Their direct 
detection and evaluation is difficult, electron spin resonance techniques usually being applied (Koleva et al. 2000). Methods for detection or monitoring these radicals, or compounds which present scavenger effects over these radicals, include CL methods based on reactions such as luminol, pirogallol or Cypridina luciferin.

Suzuki et al. (1998) report methods for detecting active oxygen species (singlet oxygen and superoxide anion) using chemiluminescence phenomena. For singlet oxygen detection, its light emission in the near-infrared (1268 nm) is utilized. The authors make an application for measuring reaction rate constant of some chemiluminescent compounds and superoxide dismutase with ${ }^{1} \mathrm{O}_{2}$. The rate constants were measured by quenching the $1268 \mathrm{~nm}$ emission. They have also developed a method for measuring reaction rate constant of antioxidants with $\mathrm{O}_{2}{ }^{-}$, using quenching experiment of $\mathrm{CL}$ of Cypridina luciferin analogues and superoxide by superoxide dismutase. On the other hand, chemiluminescence from Cypridina luciferin has been used (Kruk et al., 2000) for determining the effects of thymoquinone (TQ), thymol (TOH) and dithymoquinone $\left(\mathrm{TQ}_{2}\right)$ [constituents of the volatile oil of black seed (Nigella Sativa Linn)] on reactions generating reactive oxygen species. The effect of $\mathrm{TOH}, \mathrm{TQ}$ and $\mathrm{TQ}_{2}$ on a light emission arising from the enzymatic (xantine-oxidase-hypoxantine-bovine albumin) and nonenzymatic system for generating $\mathrm{O}_{2}-$ were followed by a chemiluminescence method.

Luminol can emit luminescence when superoxide anion radical is present. This $\mathrm{Cl}$ reaction can serve as useful detection method for radicals or antioxidant. Decrease of chemiluminescence intensity derived from luminol and superoxide anion radical, generated from the enzyme reaction of xanthine oxidase (XO) with hypoxantine, has been investigated as a screening method for the determination of antioxidants in real samples. The LC-CL method (Ogawa et al., 1999) has been applied to extracts of green tea leaves (Thea sinensis L.). The most potent antioxidant in green tea extracts was (-)-epicatechin, detected in the extracts diluted 2000 times. The authors conclude that, though the antioxidant might inhibit the $\mathrm{CL}$ by inhibiting $\mathrm{XO}$, it prevents oxidation of luminol, and quench excited aminophthalate, as well as scavenging superoxide radical anion.

$\mathrm{CL}$ methods based on luminol reaction (in presence and in the absence of SOD) have been employed (Kondo et al., 1999) to elucidate the scavenging mechanisms of specific catechins, (-)-epigallocatechin gallate (EGCG) and (-)-epicatechin gallate (ECG), on peroxyl radicals. 2,2'-Azobis(2-aminopropane) hydrochloride (AAPH), which generates peroxyl radicals by its reaction with oxygen is used as an initiator of lipid peroxidation in the liposomal system and of radical oxidation in the aqueous system. In EGC and EGCG the addition of SOD produced a remarkably inhibitory effect on $\mathrm{CL}$, which allows the authors to suggest that the pyrogallol structure in the $B$ ring, generates superoxide during the action.

Dapkevicius et al., (1999) have employed the inhibition of luminol chemiluminescence for the on-line detection of both, natural and syntethic antioxidants (rosmarinic acid, carnosic acid, $\alpha$-tocopherol, tert-butylhydroxitoluene, tertbuthylhydroquinone, carvacrol and thymol), separated by HPLC. Detection limits $\left(\mu \mathrm{g} \mathrm{ml^{-1 }}\right)$ reported by the authors were in the range 0.05 to 7.10. In a recent publication (Dapkevicius et al., 2001) these authors make an evaluation, optimization and comparison of two techniques (the on-line inhibition of luminol $\mathrm{CL}$ and the on-line 2,2'-diphenyl-1- picryhydrazyl radical (DPPH-) bleaching assay) for the on-line detection of analytes, which exhibiting radical scavenging activity, in HPLC eluates. Plant extracts of Thymus vulgaris $\mathrm{L}$. and standards of some antioxidative compounds were used for the purpose of the investigation. The authors conclude that both methods are applicable for on-line screening of samples for natural radical scavengers, elucidation of lipid peroxidation/antioxidation mechanisms and radical scavenging processes, in general. Nevertheless, the DPPH seems to be more robust .

The total reactive antioxidant potential (TRAP) of "Sangre de Drago", a red viscous latex obtained from the bark of Croton lechleri, has been measured by monitoring the intensity of luminol-enhanced chemiluminescence (Desmarchelier et al., 1997) using 2,2'-azo-bis(2-amidinopropane) as a peroxyl radical source. Results obtained suggest to the authors that Sangre de Drago is highly effective in scavenging peroxyl and hydroxyl radicals at high concentrations. Nevertheless, at lower concentrations it presented prooxidant activity. Antioxidant activity has been tested using the hydroperoxide initiated chemiluminescence assay in rat liver homogenates. The latex was effective in capturing peroxyl and hydroxyl radicals and in preventing oxidative DNA damage in aqueous. A similar study has been carried out by these authors in aqueous and methanolic extracts of several trees used in as anti-inflamatory in northeastern Brazil (Desmarchelier et al., 1999).

The chemiluminescence arising from pyrogallol oxidation, is a phenomenon during which many different $\mathrm{O}_{2}$ species are formed and each of these species contribute to different mechanisms to the overall phenomenon (Thanasoulias et al., 1999) . This fact has been used to study the influence of compounds and enzymes that trap or scavenge certain oxygen species $\left(\mathrm{NaN}_{3}\right.$ for singlet oxygen, $\mathrm{SOD}$ for 
superoxide anion, and catalase and peroxidase for $\mathrm{H}_{2} \mathrm{O}_{2}$ ) that are active in oxidation processes.

The competitive reaction rate of various antioxidants, [butylated hydroxy anisole (BHA), butylated hydroxy toluene (BHT) and $t$-butyl hydroquinone (TBHQ)] and lipids have been studied to elucidate the roles and effectiveness of antioxidant in the prevention of food oxidation by singlet oxygen (Yasaei et al. 1996). Methyl linoleate (as a model lipid) is oxidized by singlet oxygen generated by irradiating the solution with added rose bengal. The lipids and antioxidant oxidation products were analyzed by HPLC with specifics detection of the hydroperoxides by post-column chemiluminescence and/or iodometric detection. The obtained results allow to the authors conclude that, more efficient singlet oxygen scavengers that can be added to foods may be required for protection against singlet oxygen oxidation of lipids.

The hydroxylation of non chemiluminescent phthalic hydrazide by hydroxyl radicals to give the strongly chemiluminescent 3-hydroxyphthalic hydrazide supplies the basis for the CL method employed by Backa et al. (1997) for detecting hydroxyl radicals. Selectivity, sensitivity of the method and the influence of reaction conditions are presented. The authors review the applications (fungal degradation of food, in the bleaching of pulp with ozone and oxygen) of the $\mathrm{CL}$ method in both, quantitative and qualitative analyses of hydroxyl radicals.

Yildiz and Demiryüek (1998) have reported that the hydroxyl radical is generated from the reaction between ferrous iron and molecular oxygen, and this reaction induces luminol chemiluminescence. They have demonstrated that $\mathrm{CL}$ signal is significantly inhibited in a concentration-dependent manner by either superoxide dismutase (SOD) or catalase, suggesting that superoxide and $\mathrm{H}_{2} \mathrm{O}_{2}$ are simultaneously generated. At the same time, specific hydroxyl radical scavengers (mannitol and dimethyl sulfoxide) also produce attenuation of ferrous iron induced chemiluminescence. Antioxidants, urate, ascorbate and methionine produced significant inhibitions in this chemiluminescence.

Kalitchin et al (1997) have reported the antioxidant activity of four cholesteryl esters of cinnamic acid derivativesic acids (cholesteryl 2" -hydroxycinnamate, cholesteryl 3"-hydroxy cinnamate, cholesteryl 4" -hydroxycinnamate and cholesteryl 3 ",4"-hydroxycinnamate, as well as cholestanyl 2" -hydroxycinnamate) by chemiluminescence. Tetraline reaction medium is chosen for this purpose due to its well known chemiluminescence and rate constant in oxidation radical chain reaction. The oxidation is initiated by azo-bis-iso-butyro nitrile. The authors reported that though all the cholesteryl ester were efficient radical acceptors, cholesteryl 3",4"-hydroxycinnamate resulted particularly efficient radical scavenger. Furthermore, the activity of the inhibitors studied was comparable with that of $\beta$-naphthol, resorcinol and hydroquinone, determined in tetraline at $353 \mathrm{~K}$. In a later report (Kalitchin et al. 1998), these authors continued making comparative studies on the antioxidant properties of cholestheryl esters of substituted cinnamic acids by chemiluminescence, in order to evaluate the effect of the metoxy group on their antioxidant properties.

Enhanced chemiluminescence and photochemiluminescence ((luminol-p-indophenol photo-induced chemiluminescence of luminol, respectively) methods have been utilized (Amarowicz and Raab, 1997) for establishing the effectiveness of leguminous extracts (white bean, pea, lentil, everlasting pea, faba bean, and broad bean) as natural antioxidants. All extracts of leguminous seeds investigated exhibited antioxidative properties to greater or lesser degree.

Red wine is a rich source of flavonoid antioxidants. On the other hand, radical reactions are thought to play an important role during beer oxidation, and it has been demonstrated that free radicals are produced in beer and reduce quality. The determination of antioxidant capacity of wine and the deterioration of beer quality (due to oxidative changes) by chemiluminescent methods have been reviewed in a precedent paper by us (Navas and Jiménez, 1999).

A thorough and very interesting review about lipid chemiluminescence as a book chapter (Wheatley, 1999) summarizes the scope of chemiluminescent methods on this topic including sections dedicated to chemiluminescent antioxidant assays or lipid peroxidation detection by $\mathrm{Cl}$ methods based on different $\mathrm{Cl}$ reactions (Luminol, peroxalates...) and electrogenerated and ultraweak chemiluminescence.

\section{CHEMILUMINESCENCE AND OLIVE OIL}

Flavonoids and other plant-derived phenolic compounds are known to exert strong anti-oxidative activity. It is known that the plant seeds, which are the source of edible oils, including olive oil, are abundant in these antioxidant compounds. These can help to protect against degenerative disorders of the cardiovascular system.

Miyazawa et al. (1995) and Sugawara et al. (1999) have analysed oils including olive oil. Mono-, bis-, and tris- hydroperoxides of triacylglycerols formed during autoxidation and photosensitised oxidation of oils were determined by reversed-phase high-performance liquid chromatography in combination with chemiluminescence detection. Later, this investigation group (Sugawara et al., 1999) studied by the same technique the determination of triglyceride hydroperoxides in olive 
oils. The authors concluded that the CL-HPLC method, specific for the detection of hydroperoxides, should prove useful in studies of triacylglycerol oxidation in vegetable oils.

The suppression of the oxidation of triglyceride and methylesters of olive oil by additives of natural phenolic acids at $100^{\circ} \mathrm{C}$ was studied by Kasaikina et al. (1997). The rate constants of the interaction of these acids with peroxyl radicals in the oxidation of cumene at $60^{\circ} \mathrm{C}$ were determined by chemiluminescence method. The authors reported that the caffeic acid is the most efficient lipid antioxidant, exceeding ionol and $\alpha$-tocopherol.

Table I

\section{Analyte determination by chemiluminescence in seawater}

\begin{tabular}{|c|c|c|c|c|c|}
\hline ANALYTE & $\begin{array}{c}\text { DETERMINATION } \\
\text { BY }\end{array}$ & OBSERVATIONS & CL REACTION & $\begin{array}{c}\text { DETECTION LIMIT OR } \\
\text { MDC }^{\star}\end{array}$ & REFERENCE \\
\hline Cobalt (II) & $\mathrm{FIA}-\mathrm{CL}$ & $\begin{array}{l}\text { Column preconcentration } \\
\text { using 8-quinolol immobilized } \\
\text { on silica gel }\end{array}$ & $\begin{array}{l}\text { Gallic acid-hydrogen } \\
\text { peroxide system }\end{array}$ & $0,62 \mathrm{ng} \mathrm{L}^{-1}(3 \mathrm{~S})$ & Hirata et al. (1996) \\
\hline $\begin{array}{l}\text { Sulfur-containing } \\
\text { compounds }\end{array}$ & $\begin{array}{l}\text { GC with open } \\
\text { tubular columns- } \\
\text { CL detection }\end{array}$ & & Specific sulfur detector & $0,1 \mathrm{ng} \mathrm{L}^{-1}$ & $\begin{array}{l}\text { Savuk et al. } \\
(1995)\end{array}$ \\
\hline $\begin{array}{c}\text { Arsenic }(\mathrm{V}) \\
\text { Phosphorus }(\mathrm{V})\end{array}$ & FIA - CL & $\begin{array}{l}\text { Prior separation by ion } \\
\text { chromatography. } \\
\text { Applied to analyses of a } \\
\text { seaweed reference material } \\
\text { CRM } 9 \text { Sargasso }\end{array}$ & $\begin{array}{l}\text { Luminol in an } \mathrm{NaOH} \\
\text { medium. Acid solution } \\
\text { of molybdate added of } \\
\text { metavanadate ion }\end{array}$ & $\begin{array}{l}10 \mu g \mathrm{~L}^{-1} \\
1 \mathrm{mg} \mathrm{L}^{-1}\end{array}$ & $\begin{array}{l}\text { Fujiwara et al. } \\
\qquad(1996)\end{array}$ \\
\hline Ozone & CL-ozone sensor & $\begin{array}{l}\text { On line measurement of the } \\
\text { vertical turbulent ozone flux }\end{array}$ & $\begin{array}{l}\text { CL of an organic dye } \\
\text { adsorbed on silica gel in } \\
\text { the reaction with ozone }\end{array}$ & $<0,1 \mathrm{ppb}$ & $\begin{array}{l}\text { Güsten et al. } \\
(1997)\end{array}$ \\
\hline \multirow[t]{2}{*}{$\begin{array}{l}\text { Hydrogen } \\
\text { peroxide }\end{array}$} & \multirow[t]{2}{*}{ FIA - CL } & $\begin{array}{l}\text { The authors study the } \\
\text { photogeneration of } \mathrm{H}_{2} \mathrm{O}_{2} \text { in } \\
\text { marine waters }\end{array}$ & $\begin{array}{l}\text { Luminol- } \mathrm{Co}(\mathrm{II})-\mathrm{H}_{2} \mathrm{O}_{2} \text { in } 0,1 \\
M \text { sodium carbonate }\end{array}$ & $\begin{array}{c}10,6 \mathrm{nM} \mathrm{H}_{2} \mathrm{O}_{2} \\
\text { (signal-to-noise=3) }\end{array}$ & $\begin{array}{l}\text { Price et al. } \\
\quad(1998)\end{array}$ \\
\hline & & $\begin{array}{l}\text { Intercomparison with } \\
\text { fluorescence decay } \\
\text { technique }\end{array}$ & $\begin{array}{l}\text { 10-methyl-9-(p- } \\
\text { formylphenyl)-acridinium } \\
\text { carboxylate } \\
\text { trifluoromethanesulfonate } \\
\text {-hydrogen peroxide }\end{array}$ & $5 \mathrm{nM}$ & $\begin{array}{l}\text { Cooper et al. } \\
\qquad(2000)\end{array}$ \\
\hline $\begin{array}{c}\text { Copper } \\
\text { complexation }\end{array}$ & FIA - CL & $\begin{array}{c}\text { Without preconcentration } \\
\text { and with minimal sample } \\
\text { perturbation }\end{array}$ & $\begin{array}{c}\text { Reaction of copper with } \\
\text { 1,10-phenantroline- } \\
\text { hydrogen peroxide }\end{array}$ & $\begin{array}{c}0,1 \mathrm{nM} \text { in undiluted } \\
\text { seawater }\end{array}$ & $\begin{array}{c}\text { Zamzow et al. } \\
(1998)\end{array}$ \\
\hline Manganese & FIA - CL & $\begin{array}{c}\text { Iron species removed } \\
\text { through a 8-quinolinol } \\
\text { chelate resin column } \\
\end{array}$ & Luminol- $\mathrm{H}_{2} \mathrm{O}_{2}$ & $\begin{array}{c}0,029 \mathrm{nM} \text { (lower) } \\
4 \mathrm{mM} \text { (upper) } \\
\end{array}$ & $\begin{array}{c}\text { Okamura et al. } \\
(1998)\end{array}$ \\
\hline Iron & $\mathrm{FIA}-\mathrm{CL}$ & $\begin{array}{l}\text { Prior preconcentration using } \\
\text { 8-hydroxiquinoline } \\
\text { On hydrophilic vinyl polymer } \\
\text { using Toyopearl HW-40C } \\
\text { resin }\end{array}$ & $\begin{array}{c}\text { Fe-catalysed oxidation } \\
\text { of luminol by hydrogen } \\
\text { peroxide and } \\
\text { tryethilene } \\
\text { tetramine as sensitizer }\end{array}$ & $\begin{array}{l}0.021 \mathrm{nM}(3 \mathrm{~S}) \\
\text { (averanging) }\end{array}$ & $\begin{array}{l}\text { Jong et al. } \\
(1998) \\
\text { Jong et al. } \\
(2000)\end{array}$ \\
\hline $\begin{array}{l}\text { Total dissolved } \\
\text { iron }\end{array}$ & FIA - CL & $\begin{array}{l}\text { Prior reduction with sulfite } \\
\text { and preconcentration on an } \\
\text { 8-hydroxyquinoline } \\
\text { chelating resin column }\end{array}$ & $\begin{array}{l}\text { Oxidation of luminol } \\
\text { catalized by Fe } \\
\text { ions, emitting blue } \\
\text { light }\left(\lambda_{\max } 440 \mathrm{~nm}\right)\end{array}$ & $40 \mathrm{pM}(3 \mathrm{~S})$ & $\begin{array}{l}\text { Bowie et al. } \\
\text { (1998) }\end{array}$ \\
\hline $\begin{array}{l}\text { Iron (II) } \\
\text { and } \\
\text { Total iron }\end{array}$ & FIA - CL & $\begin{array}{c}\text { preconcentration on an } \\
\text { Amberlite XAD-4 resin } \\
\text { functionalized with N- } \\
\text { hydroxy } \\
\text { ethylethylenediamine }\end{array}$ & $\begin{array}{l}\text { Brilliant sulfoflavine and } \\
\mathrm{H}_{2} \mathrm{O}_{2} \text { reagent sol. }\end{array}$ & $\begin{array}{l}\text { Iron (II) } 0,80 \mathrm{nmol} \mathrm{L}^{-1} \\
\text { in sea water samples } \\
\text { using a concentration of } \\
2 \mathrm{nmol}^{-1} \text { iron (II). }\end{array}$ & $\begin{array}{l}\text { Hirata et al. } \\
\text { (1999) }\end{array}$ \\
\hline Cobalt (II) & FIA - CL & $\begin{array}{l}\text { Prior preconcentration using } \\
\text { 8-hydroxyquinoline } \\
\text { immobilized in Toyopearl }\end{array}$ & $\begin{array}{l}\text { Pyrogallol-hydrogen } \\
\text { peroxide-sodium } \\
\text { hydroxide }\end{array}$ & $5 \mathrm{pM}(3 \mathrm{~S})$ & $\begin{array}{l}\text { Cannizzaro et al. } \\
(2000)\end{array}$ \\
\hline Iron (II+III) & & $\begin{array}{c}100 \mu \mathrm{M} \mathrm{Na} \mathrm{SO}_{3} \text { as iron (III) } \\
\text { reducing agent }\end{array}$ & $\begin{array}{c}\text { Luminol-disolved oxigen } \\
\text { as the oxidant }\end{array}$ & $40 \mathrm{pM}(3 \mathrm{~S})$ & \\
\hline Phosphorus & & $\begin{array}{c}\text { Sorption preconcentration of } \\
\text { phosphorus as a yellow } \\
\text { vanadomolybdophosphoric } \\
\text { heteropoly acid (HPA) }\end{array}$ & $\begin{array}{c}\text { Alkaline-luminol } \\
\text { reaction and HPA as } \\
\text { oxidant }\end{array}$ & $\begin{array}{l}0.02 \mu \mathrm{g} \text { of } \mathrm{P} \mathrm{L}^{-1} \text { (in the } \\
\text { presence of surfactant) } \\
0.1 \mu \mathrm{g} \text { of } \mathrm{P} \mathrm{L}^{-1} \text { (in the }\end{array}$ & $\begin{array}{l}\text { Zui and Birks } \\
\qquad(2000)\end{array}$ \\
\hline
\end{tabular}


Table II

\section{CL applications in pharmaceutical analysis}

\begin{tabular}{|c|c|c|c|c|}
\hline ANALYTE & CL METHOD & OBSERVATION & DETECTION LIMITS & REFERENCE \\
\hline Ascorbic acid & $\begin{array}{l}\text { Inhibition of vit. } \mathrm{C} \text { in the } \mathrm{Cl} \text { reaction between luminol } \\
\text { and ferricyanide }\end{array}$ & $\begin{array}{l}\text { Luminol and ferricyanide immobilized on an } \\
\text { anion-exchange resin column }\end{array}$ & $5,5 \times 10^{-3} \mu \mathrm{g} \mathrm{ml}^{-1}$ & Zhang and Qin., (1996) \\
\hline Vitamin $B_{12}$ & $\begin{array}{l}\text { Cathalytic effect of cobalt(II) on the CL reaction } \\
\text { between luminol and hydrogen peroxide }\end{array}$ & $\begin{array}{l}\text { Luminol im mobilized electrostatically on an } \\
\text { anion-exchange column, and hydrogen } \\
\text { peroxide electrochemically generated }\end{array}$ & $3,5 \times 10^{-4} \mathrm{mg} \mathrm{l}^{-1}$ & Qin et al. (1997) \\
\hline $\begin{array}{l}\text { Pyridoxine } \\
\text { hydrochloride }\end{array}$ & $\begin{array}{l}\text { Enhancing effect of analyte on the } C L \text { generated by } \\
\text { the oxidation of lum inol with hydrogen peroxide in } \\
\text { aqueous potassium hydroxide and sodium oxalate }\end{array}$ & & $6 \mu \mathrm{gll}^{-1}$ & $\begin{array}{l}\text { Alwarthan and Aly } \\
\text { (1998) }\end{array}$ \\
\hline Etamsylate & $\begin{array}{l}\text { Quenching effect of the analyte in the luminol } \\
\text { hypochlorite system }\end{array}$ & $\begin{array}{c}\text { Electrogenerated unstable reagent in a flow } \\
\text { injection setup }\end{array}$ & $6 \times 10^{-10} \mathrm{~g} \mathrm{ml}^{-1}$ & Zhang et al. (1998a) \\
\hline $\begin{array}{l}\text { cathecholamines } \\
\text { (dopamine, } \\
\text { adrenaline and } \\
\text { isoprenaline) }\end{array}$ & $\begin{array}{c}\text { Inhibition of the intensity of the } C L \text { from the luminol- } \\
\text { hypochlorite system }\end{array}$ & $\begin{array}{l}\text { The hypoclorite was generated } \\
\text { electrochemically on-line }\end{array}$ & $\begin{array}{c}\text { Dopamine: } 6 \times 10^{-10} \mathrm{~g} \\
\mathrm{ml}^{-1} \\
\text { Adrenaline: } 8 \times 10^{-10} \mathrm{~g} \\
\mathrm{ml}^{-1} \\
\text { Isoprenaline: } 8 \times 10^{-10} \mathrm{~g} \\
\mathrm{ml}^{-1}\end{array}$ & Zhang et al. (1998b) \\
\hline Tannic acid & $\begin{array}{c}\text { Inhibition of the } \mathrm{CL} \text { of the luminol- } \mathrm{H}_{2} \mathrm{O}_{2}-\mathrm{Cu}^{++} \text {system } \\
\text { by tannic acid }\end{array}$ & & $9 \times 10^{-9} \mathrm{moll}^{-1}$ & Cui et al. (1998) \\
\hline$\beta$-lactam antibiotics & $\begin{array}{c}\mathrm{CL} \text { was directly produced by the reaction of } \beta \text {-lactam } \\
\text { antibiotics with lum inol in the presence of a catalyst } \\
\text { in an alkaline solution without } \mathrm{H}_{2} \mathrm{O}_{2}\end{array}$ & $\begin{array}{c}\text { hexacyanoferrate (III) and hexacyanoferrate (II) } \\
\text { were used as catalyst }\end{array}$ & $\begin{array}{c}\text { Between } 2 \times 10^{-1} \text { to } 20 \\
\mu \mathrm{g} \mathrm{ml^{-1 }}\end{array}$ & Kubo et al. (1999) \\
\hline Isoniazid & $\begin{array}{c}\text { Enhancement effect of analyte on the week emission } \\
\text { of light produced by } \mathrm{CL} \text { reaction between } \mathrm{BrO}^{-} \text {and } \\
\text { luminol }\end{array}$ & $\begin{array}{l}\text { The } \mathrm{BrO}^{-} \text {was electrogenerated on-line in } \mathrm{KBr} \\
\text { solution }\end{array}$ & $7 \times 10^{-9} \mathrm{~g} \mathrm{ml}^{-1}$ & $\begin{array}{l}\text { Zheng and Zhang } \\
\text { (1999) }\end{array}$ \\
\hline Lactate & $\begin{array}{l}\mathrm{Fe}^{2+} \text { generated detected by the } \mathrm{CL} \text { reaction of } \\
\text { luminol system without added oxidant }\end{array}$ & $\begin{array}{l}\text { Decomposition of lactate in the presence of } \\
\mathrm{UO}_{2}^{2+} \text { and } \mathrm{Fe}^{3+} \text {, and production of } \mathrm{Fe}^{2+}\end{array}$ & $2 \mathrm{ng} \mathrm{ml}^{-1}$ & $\begin{array}{l}\text { Pérez-Ruiz et al. } \\
\text { (1999a) }\end{array}$ \\
\hline Vitamin $\mathrm{K}_{3}$ & $\begin{array}{l}\text { Monitorization of } \mathrm{H}_{2} \mathrm{O}_{2} \text { produced by } \mathrm{CL} \text { reaction with } \\
\text { luminol catalysed by hematin }\end{array}$ & $\begin{array}{l}\text { Photooxidation of ethanol sensitized by vitam in } \\
\qquad \mathrm{K}_{3} \text { to yield } \mathrm{H}_{2} \mathrm{O}_{2}\end{array}$ & $2,03 \times 10^{-9} \mathrm{moll}^{-1}$ & $\begin{array}{l}\text { Pérez-Ruiz et al. } \\
\text { (1999b) }\end{array}$ \\
\hline Chloramphenicol & $\begin{array}{c}C L \text { detection of photolytic fragments whit luminol - } \\
\text { Co(II) system }\end{array}$ & Photodegradation of nitro compounds & $3 \times 10^{-9} \mathrm{~mol} \mathrm{l}^{-1}$ & David et al. $(2000)$ \\
\hline $\begin{array}{l}\text { Sulbactam sodium } \\
\text { and clavulanic acid }\end{array}$ & $\begin{array}{l}\text { Enhancing effect on the } \mathrm{CL} \text { generated by the } \\
\text { oxidation of luminol with } \mathrm{H}_{2} \mathrm{O}_{2} \text { in alkaline medium }\end{array}$ & & $\begin{array}{c}\text { Sulbactam sodium: } \\
0,05 \mu \mathrm{g} \mathrm{ml^{-1 }} . \\
\text { Clavulanic acid: } 0,01 \\
\mu \mathrm{g} \mathrm{ml^{-1 }}\end{array}$ & Aly et al. (2000a) \\
\hline Atropine & $\begin{array}{c}\text { Analytical CL signal produced by } \\
\text { cetyltrimethylammonium chloride - luminol - ion pair } \\
\text { complex of tetrachloroaurate (III) with atropinium }\end{array}$ & $\begin{array}{c}\text { On line ion-pair formation and solvent extraction } \\
\text { method copupled with reversed micellar } \\
\text { mediated } C L\end{array}$ & & Fujiwara et al. (2000) \\
\hline
\end{tabular}

\begin{tabular}{|c|c|c|c|c|}
\hline Penicillamine & $\begin{array}{l}\mathrm{CL} \text { reaction of thiol containing drugs with } \mathrm{Ce}(\mathrm{IV}) \text { in } \\
\qquad \mathrm{H}_{2} \mathrm{SO}_{4} \text { medium }\end{array}$ & Quinine as fluorescer & 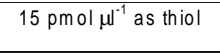 & Zhang et al. (1996) \\
\hline Tiopronin & Oxidation by $\mathrm{Ce}$ (IV) in dilute sulfuric medium & Sensitized by quinine & $0,34 \mu \mathrm{M}$ & Zhao et al. (1997) \\
\hline Some phenothiazines & $\begin{array}{c}C L \text { induced by the oxidation of drugs with } \mathrm{Ce} \text { (IV) in } \\
\text { acid medium }\end{array}$ & Rhodamine $B$ as sensitizer & $\begin{array}{c}\text { Fluphenazine } \\
\text { hydrochloride: } \\
0.01 \mu \mathrm{ml}^{-1} \\
\text { Levomepromazine } \\
\text { hydrochloride and } \\
\text { trimeprazine tartrate: } \\
0,1 \mu \mathrm{g} \mathrm{m}^{-1}\end{array}$ & Aly et al. (1998a) \\
\hline Tiopronin & $\begin{array}{c}C L \text { reaction of tiopronin with } \mathrm{Ce}(\mathrm{IV}) \text { in sulfuric acid } \\
\text { medium }\end{array}$ & Rhodamine $6 \mathrm{G}$ and quinine as fluorophors & $3,6 \times 10^{-8} \mathrm{M}$ & Pérez-Ruiz et al. (1998) \\
\hline Hydrochlorothiazide & $\begin{array}{c}\mathrm{CL} \text { reaction of hydrochlorothiazide with } \mathrm{Ce}(\mathrm{IV}) \text { in } \\
\text { sulfuric acid }\end{array}$ & Sensitized by rhodam ine $6 \mathrm{G}$ & $0,15 \mu \mathrm{moll}^{-1}$ & Ouyang et al. (1998) \\
\hline Analgin & $\begin{array}{c}C L \text { reaction of analgin with } \mathrm{Ce}(\mathrm{IV}) \text { sulfate in sulfuric } \\
\text { acid }\end{array}$ & Sensitized by Rhodamine $6 \mathrm{G}$ & $0,02 \mathrm{mg} \mathrm{ml}^{-1}$ & Huang et al. (1999) \\
\hline $\begin{array}{l}\text { Hydrochlorothiazide } \\
\text { and captopril }\end{array}$ & $C L$ reaction with $C e$ (IV) in sulfuric acid medium & Sensitized by rhodam ine $6 \mathrm{G}$ & $\begin{array}{c}\text { Hydrochlorothiazide: } \\
0,2 \mu \mathrm{mol} \mathrm{I} \mathrm{I}^{-1} \mathrm{C} \text { aptopril: } \\
2,7 \mathrm{moll}^{-1}\end{array}$ & Ouyang et al. (1999) \\
\hline $\begin{array}{c}\text { Sodium 2- } \\
\text { mercaptoethane } \\
\text { sulfonate } \\
\end{array}$ & $\begin{array}{l}C L \text { reaction of thiol with } \mathrm{Ce}(\mathrm{IV}) \text { in sulfuric acid } \\
\text { medium }\end{array}$ & Quinine as sensitizer & $1,38 \mu \mathrm{gl}^{-1}$ & $\begin{array}{l}\text { Capitán-Vallvey et al. } \\
\qquad(2000)\end{array}$ \\
\hline $\begin{array}{l}\text { Cefadroxil } \\
\text { monohydrate }\end{array}$ & $\begin{array}{c}C L \text { reaction of analyte with potassium permanganate } \\
\text { in sulfuric acid }\end{array}$ & Sensitized by quinine & $0,05 \mu \mathrm{g} \mathrm{ml}^{-1}$ & Aly et al. (1998b) \\
\hline Naltrexone & $\begin{array}{c}C L \text { reaction with potassium perm anganate in sulfuric } \\
\text { acid medium }\end{array}$ & without FIA & $25 \mathrm{ng} \mathrm{ml}^{-1}$ & Campliglio (1998) \\
\hline Perphenazine & $\begin{array}{c}\mathrm{CL} \text { reaction with potassium permanganate in sulfuric } \\
\text { acid medium }\end{array}$ & Method with flow injection & & Sultan et al. (1999) \\
\hline $\begin{array}{l}\text { Salbutamol and } \\
\text { ranitidine }\end{array}$ & $\begin{array}{c}\mathrm{CL} \text { reaction with acid potassium permanganate in } \\
\text { sodium polyphosphate }\end{array}$ & $\begin{array}{l}\text { Weak } \mathrm{CL} \text { from the reaction between ranitidine } \\
\text { and } \mathrm{KMnO}_{4}\end{array}$ & $\begin{array}{c}\text { Salbutamol: } \\
2,5 \times 10^{-8} \mathrm{M} \\
\text { Ranitidine: } 1 \times 10^{-5} \mathrm{M}\end{array}$ & Barnett et al. (1999) \\
\hline Salicylam ide & $\begin{array}{c}\text { Oxidation of the drug by potassium permanganate in } \\
\text { dilute sulfuric acid }\end{array}$ & A FI method for salicylamide & $30 \mathrm{ng} \mathrm{ml}^{-1}$ & $\begin{array}{c}\text { Fuster Mestre et al. } \\
(1999)\end{array}$ \\
\hline $\begin{array}{l}\text { Procaine, benzocaine } \\
\text { and tetracaine }\end{array}$ & $\begin{array}{l}\text { Oxidation of the analytes by permanganate in sulfuric } \\
\text { acid in the presence of various } C L \text { enhancers }\end{array}$ & $\begin{array}{l}\text { Determination by sequential injection analysis } \\
\text { with } C L \text { detection }\end{array}$ & $\begin{array}{c}\text { Procaine } \\
\text { hydrochloride: and } \\
\text { benzocaine: } \\
0,3 \mu \mathrm{g} \mathrm{m} \mathrm{l}^{-1} \\
\text { Tetracaine } \\
\text { hydrochloride: } \\
0,1 \mu \mathrm{g} \mathrm{m} \mathrm{l}^{-1} \\
\end{array}$ & $\begin{array}{l}\text { Paseková and Polásek } \\
(2000)\end{array}$ \\
\hline $\begin{array}{l}\text { Thioridazine } \\
\text { hydrochloride }\end{array}$ & $\begin{array}{c}\text { Oxidation by potassium permanganate in acidic } \\
\text { medium }\end{array}$ & Flow-injection analysis & $1,2 \times 10^{-6} \mathrm{M}$ & Kojlo et al. (2000) \\
\hline
\end{tabular}


Table II (Cont.)

\begin{tabular}{|c|c|c|c|c|}
\hline Codeine & $\begin{array}{l}\mathrm{Ru}(\mathrm{bpy})_{3}{ }^{2+} \text { and codeine are oxidized and upon } \\
\text { reacting generate the excited product }{ }^{2} \text { Rubpy }{ }_{3}{ }^{2+}\end{array}$ & Complex immobilized in a sintetic matrix & $20 \mu \mathrm{M}$ & Michel et al. (1999a) \\
\hline Codeine & $\begin{array}{l}\text { Ruthenium complex }\left(\mathrm{Ru}(\mathrm{bpy})_{3}{ }^{2+} \text { and }\right. \\
\left.\mathrm{Ru}(\mathrm{bpy})_{2}(\text { phen })^{2+}\right) \text { and codeine are oxidized and } \\
\text { upon reacting generate the excited product }\end{array}$ & $\begin{array}{l}\text { Measurements carried out in batch and FIA } \\
\text { mode }\end{array}$ & $\begin{array}{c}\mathrm{Ru}(\mathrm{bpy})_{3}{ }^{2+} \text { and batch } \\
\text { mode: } 0,5 \mu \mathrm{M} \\
\mathrm{Ru}(\mathrm{bpy})_{2}(\mathrm{phen})^{2+} \text { and } \\
\text { batch mode: } 0,1 \mu \mathrm{M} \\
\mathrm{Ru}(\mathrm{bpy})_{3}{ }^{2+} \text { and } \mathrm{FIA} \\
\text { mode: } 100 \mu \mathrm{M} \\
\mathrm{Ru}(\mathrm{bpy})_{2}(\mathrm{phen})^{2+} \text { and } \\
\mathrm{FIA} \text { mode: } 50 \mu \mathrm{M}\end{array}$ & Michel et al. (1999b) \\
\hline $\begin{array}{c}\text { Tricyclic } \\
\text { antidepressants }\end{array}$ & $\begin{array}{c}\mathrm{CL} \text { reaction between } \mathrm{Ru}(\mathrm{bpy})_{3}{ }^{2+} \text { and the tertiary } \\
\text { am ino groups }\end{array}$ & & $\begin{array}{l}\text { A mitriptyline: } \\
0,09 \mu \mathrm{m} \mathrm{m} l^{-1} \\
\text { Doxepin: } 010 \mu \mathrm{ml}^{-1} \\
\text { Nortriptyline: } \\
0,31 \mu \mathrm{g} \mathrm{m} \mathrm{l}^{-1} \\
\text { Promazine: } \\
0,16 \mu \mathrm{g} \mathrm{ml}^{-1} \\
\text { Chlorpromazine: } \\
0,24 \mu \mathrm{g} \mathrm{ml}^{-1}\end{array}$ & $\begin{array}{c}\text { Greenway and Dolman } \\
\text { (1999) }\end{array}$ \\
\hline Ranitidine & $\begin{array}{l}\mathrm{CL} \text { reaction between } \mathrm{Ru}(\mathrm{bpy})_{3}{ }^{2+} \text { and a tertiary and } \\
\text { two secundary amine groups }\end{array}$ & Flow injection analysis with $\mathrm{CL}$ detection & $6 \times 10^{-7} \mathrm{M}$ & Barnett et al. (1999) \\
\hline Tetracyclines & $\begin{array}{l}\mathrm{CL} \text { system of } \mathrm{Ru}(\mathrm{bpy})_{3}{ }^{2+} \text { oxidized by acidic } \\
\text { permanganate in presence of } \mathrm{Mn} \text { (II) }\end{array}$ & $\begin{array}{c}\text { The light emission intensity is enhanced when } \\
\text { the analyte are also present in the reaction } \\
\text { system }\end{array}$ & $\begin{array}{l}\text { Tetracycline: } \\
2,0 \times 10^{-8} \mathrm{~g} \mathrm{ml}^{-1} \\
\text { Chlortetracycline: } \\
1,0 \times 10^{-8} \mathrm{~g} \mathrm{ml}^{-1} \\
\text { Oxytetracycline: } \\
2,0 \times 10^{-8} \mathrm{~g} \mathrm{ml}^{-1}\end{array}$ & Han et al. (1999) \\
\hline Codeine & $\mathrm{Ru}($ bpy $){ }^{2+} \mathrm{CL}$ reaction & Miniature electrochemiluminescence detector & $100 \mu \mathrm{M}$ & L'Hostis et al. (2000) \\
\hline $\begin{array}{l}\text { Flufenamic and } \\
\text { mefenamic acids }\end{array}$ & $\mathrm{Ru}(\mathrm{bpy})_{3}{ }^{2+} \mathrm{CL}$ reaction & $\begin{array}{c}\text { Chemical generation of } \mathrm{Ru}(\mathrm{bpy})_{3}{ }^{3+} \text { by mixing } \\
\text { two streams containing solution of } \mathrm{Ru}(\mathrm{bpy})_{3}{ }^{2+} \\
\text { and acid } \mathrm{Ce}(\mathrm{IV})\end{array}$ & $\begin{array}{c}\text { Flufenamic acid: } \\
3,6 \times 10^{-9} \mathrm{M} \\
\text { Mefenamic acid: } \\
2,1 \times 10^{-7} \mathrm{M}\end{array}$ & Aly et al. (2000b) \\
\hline $\begin{array}{l}\text { Fluoroquinolone } \\
\text { derivatives }\end{array}$ & $\begin{array}{c}\mathrm{CL} \text { reaction of analyte with } \mathrm{Ru}(\mathrm{bpy})_{3}{ }^{2+} \text { and } \mathrm{Ce}(\mathrm{IV}) \text { in } \\
\text { sulfuric acid medium }\end{array}$ & $\begin{array}{l}\mathrm{Ce}(\mathrm{IV}) \text { used to produce } \mathrm{Ru}(\mathrm{bpy})_{3}{ }^{3+} \text { wich is used } \\
\text { for determination of analyte }\end{array}$ & $\begin{array}{c}\text { Norfloxanin: } \\
26 \times 10^{-8} \mathrm{M} \\
\text { Ciprofloxacin: } \\
2,6 \times 10^{-8} \mathrm{M} \\
\text { Ofloxacin: } 5.5 \times 10^{-9} \mathrm{M}\end{array}$ & Aly et al., (2001) \\
\hline
\end{tabular}

De la Puerta et al. (1999) have employed the CL to study the effects of polyphenolic compounds from virgin olive oils (tyrosol, hydroxytyrosol, oleuropein and caffeic acid) in the inhibition of leukocite 5-lipoxygenase by the quenching effect produced on the $\mathrm{CL}$ signal due to reactive oxygen species generated by phorbol myristate acetate-stimulated rat leukocytes. This same investigation group (Gutierrez et al., 2001) have examined the effects of polyphenolic compounds from virgin olive oils on the non-enzymatic lipid peroxidation induced by ascorbate- $\mathrm{Fe}^{++}$of rat liver microsomes by chemiluminescence. The obtained result showed that the principal phenolics present within the polar fraction of Virgin olive oil possess an array of potentially beneficial lipoxygenase-inhibitory, prostaglandin-sparing, and antioxidant properties.

Sawa et al. (1998) and Kanazawa et al. (2000) have quantified the generation of lipid peroxyl radicals (LOO) from oxidized oils and edible oils (including Extra virgin and Virgin olive oils) by means of a luminol-enhanced chemiluminescence assay and their implication in human health. The authors concluded that a large proportion of anti-oxidant activity, as well as radical scavenging of edible oils can be lost by the conventional process of oil refining and they report as Extra virgin and Virgin olive oils are rich in LOO Scavengers, so they are preferred not only for an anticarcinogenic potential, but also for prevention of reactive oxygen related diseases.

\section{ANALYTE SEAWATER DETERMINATION BY CHEMILUMINESCENCE}

Most of the water of the Earth's surface is in the ocean. Because of its chemical and physical properties, this water has had a great influence on the continuing biochemical evolution of this planet (Libes, 1992). Seawater constitutes a source of a wide variety of chemical ions considered as major constituents $\left(\mathrm{Mg}^{2+}, \mathrm{Cl}^{-}, \mathrm{Na}^{+}, \mathrm{Ca}^{2+}, \mathrm{SO}_{4}{ }^{2-} \ldots\right)$, nevertheless, there are a great number of other elements or compounds which exist at trace levels and exhibit an important function in marine geochemistry,for instance, iron and manganese are known to be essential micronutrients for marine organisms. The analysis of ultra-trace elements in seawater samples is one of the most difficult analytical tasks in the field of environmental monitoring as extremely low detection limits for elements "buried" in a highly saline matrix are required (Ferradello et al. 2001).

One of the utilities of Chemiluminescent methods in Analytical Chemistry is the determination of trace metals due to the fact that a great deal of CL reactions require the presence of metal just as a catalyst or by its redox properties. The application of CL methods to seawater analysis is compiled in Table I.

\section{CHEMILUMINESCENCE IN PHARMACEUTICAL SAMPLES}


Accurate determination of drugs in pharmaceutical preparations is very important in the pharmaceutical industries. A variety of techniques have been used in the determination such as spectrophotometry (Travis et al., 1999; Sakiara et al, 1999, Altinoz and Dursun, 2000), spectrofluorimetry (Gatti et al., 2000, Rizk et al., 2000), electrochemical detection (Yun et al., 1999, Wang, 2000), etc. The analytical evaluation of commercially significant pharmaceutical drugs using chemiluminescence detection has attracted considerable attention in recent years, due to their higher sensitivity and their very simple instrumentation (no monochromator required). Moreover, the reproducibility and selectivity can be excellent by combination with a flow injection method.

Table II summarises the most important CL application to the determination of drugs in pharmaceutical preparation. The $\mathrm{CL}$ reaction of luminol can serve as a basis for the determination of analytes which can enhance (pyridoxine hydrochloride, isoniazid, sulbactam sodium or clavulanic acid) or inhibit (ascorbic acid, etamsylate, some cathecholamines or tannic acid) the chemiluminescence. Furthermore, other analytes can be determined because they directly react with luminol ( $\beta$-lactam antibiotics) or they produce some compound that would react with luminol (lactate or vitamin $\mathrm{K}_{3}$ ).

Other interesting pharmaceutical analytes can be oxidised by $\mathrm{Ce}$ (IV) in sulfuric acid medium and this CL reaction can assist in their quantification. The reaction can be sensitised by several fluorophors, such as quinine (penicillamine, tiopronin, or sodium 2-mercaptoethane sulfonate) and rhodamine 6G (some phenothiazines, tiopronin, hydrochlorothiazide, analgin or captopril). In the same way, some drugs can be oxidised and determined by potassium permanganate in a sulfuric acid medium. Usually, the method implies a FIA procedure but Campliglio (1998) proposes the determination without FIA.

Numerous analytical applications of orange emission of tris(2,2'-bipyridiyl)ruthenium(II) in acid solution have appeared in literature. In the table we have summarised some analytical applications in pharmaceutical preparation as determination of codeine, tricyclic antidepressants, ranitidine, tetracyclines, some fluoroquinolone derivatives or flufenamic and mefenamic acids.

\section{CONCLUSIONS}

With the increasing demand for highly sensitive and selective analyses in many areas of analytical sciences, chemiluminescence techniques continue to provide important and fascinating fields of research.
In this paper we have selected and reviewed the most recent literature in relation to three relevant fields of scientific, clinical, and environmental interest, in order to show how chemiluminescence is a living technique, with a plethora of real possibilities. Likewise, we have tried to show the role that the chemiluminescence plays in the determination of the antioxidant activity of natural products, with special mention to the olive oil.

Nowadays, technological advances happen very quickly, and this has enabled CL methods to improve and has led to an increase in its fields of applications. The awareness of new CL reactions, the coupling of these new reactions with others of analytical interest and, any case, the increase of new detection systems (replacement of the photon counting photomultiplier for the photodiode) have contributed to expanding the range of the applications for $\mathrm{CL}$ techniques. We will conclude by saying that $\mathrm{CL}$ is now and it will continue being a technique capable of solving analytical problems for the new millennium.

\section{REFERENCES}

Albrecht, H.O. (1928). Chemiluminescence of aminophthalic hydrazide. Z. Phys. Chem. 136, 321.

Altinoz, S. and Dursun, O.O. (2000). Determination of nimesulide in pharmaceutical dosage forms by second order derivative UV spectrophotometry. J. Pharm. Biomed. Anal., 22, 175-182.

Alwarthan, A.A. and Aly, F.A. (1998). Chemiluminescent determination of pyridoxine hydrochloride in pharmaceutical samples using flow injection. Talanta, 45, 1131-1138.

Aly, F.A., Alarfaj, N.A. and Alwarthan, A.A. (1998a). Flow-injection chemiluminometric determination of some phenothiazines in dosage forms and biological fluids. Anal. Chim. Acta, 358, 255-262.

Aly, F.A., Alarfaj, N.A. and Alwarthan, A.A. (2000a). Sensitive assay for clavulanic acid and sulbactam in pharmaceuticals and blood serum using a flow-injection chemiluminometric method. Anal. Chim. Acta., 414, 15-23.

Aly, F.A., Al-Tamimi, S.A. and Alwarthan, A.A. (2000b). Determination of flufenamic acid and mefenamic acid in pharmaceutical preparations and biological fluids using flow injection analysis with tris(2,2'-bipyridyl) ruthenium (II) chemiluminescence detection. Anal. Chim. Acta, 416, 87-96.

Aly, F.A., Al-Tamimi, S.A. and Alwarthan, A.A. (2001). Chemiluminescence determination of some fluoroquinolone derivatives in pharmaceutical formulations and biological fluids using [Ru(bipy) $\left.3^{2+}\right]-$ Ce(IV) system. Talanta 53, 885-893.

Aly, F.A., Alarfaffj, N.A. and Alwarthan, A. (1998b). Permanganate-based chemiluminescence analysis of cefadroxil monohydrate in pharmaceutical samples and biological fluids using flow injection. Talanta 47, 471-478.

Amarowicz, R. and Raab, B. (1997). Antioxidative activity of leguminous seed extracts evaluated by chemiluminescence methods. $Z$. Naturforsch $C$, 52, 709-712. 
Backa, S., Jansbo, K. and Reitberger, T. (1997). Detection of hydroxyl radicals by a chemiluminescence method-A critical review. Holzforschun, 51, 557-564.

Barnett, N. and Lewis, S. (1996). Tripping the light fantastic. Analysis europa March/April, 28-33.

Barnett, N.W., Hindson, B.J. and Lewis, S.W. (1999). Determination of Ranitidine and Salbutamol by flow injection analysis with chemiluminescence detection. Anal. Chim. Acta, 384, 151-158.

Blache, D., Gesquiere, L., Loreau, N. and Durand, P. (1999). Oxidant Stress: The role of nutrients in cell lipoprotein interactions. Proc. Nutr. Soc., 58, 559-563.

Bowie, A.R., Achterberg, E.P., Mantoura, R.F.C. and Worsfold, P.J. (1998). Determination of sub-nanomolar levels of iron in seawater using flow injection with chemiluminescence detection. Anal. Chim. Acta, 361, 189-200.

Campiglio, A. (1998). Chemiluminescence determination of naltrexone based on potassium permanganate oxidation. Analyst, 123, 1053-1056.

Cannizzaro, V., Bowie, A.R., Sax, A., Achterberg, E.P. and Worsfold, P.J. (2000). Determination of cobalt and iron in estuarine and coastal waters using flow injection with chemiluminescence detection. Analyst, 125, 51-57.

Capitan Vallvey, L.F., Valencia Mirón, M.C. and Acosta Acosta R. (2000). Chemiluminescence determination of sodium 2-mercaptoethane sulfonate by flow injection analysis using cerium (IV) sensitized by quinine. Talanta, 51, 1155-1161.

Cooper, W., Moegling, J., Kieber, R. and Kiddle, J. (2000). A chemiluminescent method for the analysis of $\mathrm{H}_{2} \mathrm{O}_{2}$ in natural waters. Marine Chemistry 70, 191-200.

Cui, H., Li, Q., Meng, R., Zhao, H. and He, C. (1998). Flow injection analysis of tannic acid with inhibited chemiluminescent detection. Anal. Chim. Acta. 362, 151-155.

Dapkevicius, A., van Beek, T.A. and Niederländer, H.A.G. (2001). Evaluation and comparison of two improved techniques for the on-line detection of antioxidants in liquid chromatography eluates. J. of Chromatogr., 912, 73-82.

Dapkevicius, A., van Beek, T.A., Niederländer, A. and de Groot, A. (1999). On-line detection of antioxidative activity in high-performance liquid chromatography eluates by chemiluminescence. Anal. Chem., 71, 736-740.

David, V., Marín Saez, R.M., García Mateo, J.V. and Martínez Calatayud, J. (2000). Enhanced chemiluminescent determination of chloramphenicol and related nitrocompounds by "on-line" photochemical reaction. Analyst, 125, 1313-1319.

De Jong, J. T., den Das, J., Bathmann, U., Stoll, M.C., Kattner, G., Nolting, R.F. and de Baar, H.J.W. (1998). Dissolved iron at subnanomolar levels in the Southern Ocean as determined by ship-board analysis. Anal. Chim. Acta, 377, 113-124.

De la Puerta, R., Gutiérrez, V.R., Hoult, R.S. (1999). Inhibition of leukocyte 5-lipoxygenase by phenolics from virgin olive oil. Biochem. Pharmacology, 57, 445-449.

Desmarchelier, C., Lisboa Romao, R., Coussio, J. and Ciccia, G. (1999). Antioxidant and free radical scavenging activities in extracts from medicinal trees used in the 'Caatinga region in northeastern Brazil. J. Ethnopharmacol., 67, 69-77.

Desmarchelier, C., Witting Schaus, F., Coussio, J. and Cicca, G. (1997). Effects of Sangre de Drago from Croton lechleri Muell.-Arg. on the production of active oxygen radicals. J. Ethnopharmacol., 58, 103-108.
Dodeigne, C., Thunus, L. Lejeune, R. (2000). Chemiluminecence as a diagnostic tool. A review. Talanta 51, 415-439.

Ferradello, C.N. , Bayón, M.M., García Alonso, J.I. and Sanz-Medel, A. (2001). Comparison of metal pre-concentration on immobilized Kelex-100 and quadruple inductively coupled plasma mass spectrometric detection with direct double focusing inductively coupled plasma mass spectrometric measurements for ultratrace multi-element determination in sea-water. Anal. Chim. Acta. , 429, 227-235.

Fujiwara, T., Kurahashi, K., Kumamaru, T. and Sakai, H. (1996). Luminol chemiluminescence with heteropoly acids and its application to the determination of arsenate, germanate, phosphate and silicate by ion chromatography. Appl. Organomet. Chem., 10, 675-681.

Fujiwara, T., Mohammadzai, I.U., Murayama, K. and Kumamaru, T. (2000). Solvent extraction coupled on-line to a reversed micellar mediated chemiluminescence detection system for trace-level determination of atropine. Anal. Chem., 72, 1715-1719.

Fuster Mestre, Y., Lahuerta Zamora, L. and Martínez Calatayud, J. (1999). Direct flow injection chemiluminescence of salicylamide. Anal. Chim. Acta 394, 159-163.

Galeano Díaz, T. and Guiberteau Cabanillas, A. Analysis of synthetic food antioxidants, in Handbook of Food Analysis, Vol. II; edited Leo M.L. Nollet, Marcel Deker, Inc., 1996, pp. 1169-1834.

Gatti, R., Gioia, M.G. and Cavrini, V. (2000). Analysis and stability study of retinoids in pharmaceuticals by LC with fluorescence detection. J. Pharm. Biomed. Anal., 23, 147-159.

Gerardi, R.D., Barnett, N.W. and Lewis, S.W. (1999). Analytical applications of tris(2,2'-bipyridyl)ruthenium (III) as a chemiluminescent reagent. Anal. Chim. Acta 378, 1-41.

Greenway, G.M. and Dolman, S.J.L. (1999). Analysis of tricyclic antidepressants using electrogenerated chemiluminescence. Analyst, 124, 759-762.

Güsten, H., Heinrich, G., Mönnich, E., Sprung, D. and Weppner, J. On-line Measurements of Ozone Surface Fluxes: Instrumentation and Methodology, in Transp. Chem. Transform. Pollut. Troposphere, Vol. 4, edited by : Slanina, Sjaak. Springer: Berlin, 1997, pp. 201-209.

Gutierrez, V.R., De la Puerta, R., Catala, A. (2001). The effect of tyrosol, hydroxytyrosol and oleuropein on the nonenzymatic lipid-peroxidation of rat-liver microsomes. Mol. Cell. Biochem., 217, 35-41.

Han, H., He, Z. and Zeng, Y. (1999). Chemiluminescence determination of tetracyclines using a tris(2,2'-bipyridine) ruthenium (II) and potasium permanganate system. Anal. Sci. 15, 467-470.

Hirata, S., Hashimoto, Y., Masato, A. and Vitharana Mallica, G. (1996). Online column preconcentration for the determination of cobalt in sea water by flow-injection chemiluminescence detection. Fresenius J. Anal. Chem. 355, 676-679.

Hirata. S. , Yoshihara, H. and Aihara, M. (1999). Determination of iron (II) and total iron in environmental water samples by flow injection analysis with column preconcentration of chelating resin functionalized with $\mathrm{N}$-hydroxyethylethylenediamine ligands and chemiluminescence detection. Talanta, 49, 1059-1067.

Huang, X.J. and Fang, Z.L. (2000). Chemiluminescence detection in capillary electrophoresis. Anal. Chim. Acta 414, 1-14. 
Huang, Y., Zhang, C., Zhang, X. and Zhang, Z. (1999). Cerium(IV)-based chemiluminescence analysis of analgin. Anal. Lett., 32, 933-943.

Isacsson, U. and Wettermark, G. (1974). Chemiluminescence in Analytical Chemistry. Anal. Chim. Acta 68, 339-362.

Jiménez, A.M. and Navas, M.J. (1997). Chemiluminescent methods in agrochemical analysis. CRAC 27, 291-306.

Jiménez, A.M. and Navas, M.J. (1999). Chemiluminescence detection systems in supercritical fluid methods. TRAC 18, 353-361.

Jong, J.T.M. , Boye, M., Schoemann, V. F., Nolting, R.F. and Baar, H.J.W. (2000). Shipboard techniques based on flow injection analysis for measuring dissolved $\mathrm{Fe}, \mathrm{Mn}$ and Al in seawater. J. Environ. Monit. 2, 496-502.

Jong, J.T.M., den Das, J., Bathmann, U., Stoll, M.H.C., Kattner, G., Nolting, R.F. and Baar, H.J.W. (1998). Dissolved iron at subnanomolar levels in the Southern Ocean as determined by ship-board analysis. Anal. Chim. Acta 377, 113-124.

Kalitchin, Z.D., Boneva, M.I., Milkova, T. and Todorova, D. (1997). Study on the antioxidant activity of cholesteryl esters of some phenolic acids by chemiluminescence. J. Photoch. Photobio. B , 41, 109-113.

Kalitchin, Z.D., Boneva, M.I., Milkova, T. and Todorova, D. (1998). Comparative studies on the antioxidant properties of cholesteryl esters of substituted cinnamic acids in model conditions. Oxid. Commun., 21, 478-485.

Kanazawa, A., Sawa, T., Akaike, T., Morimura, S., Kida, K., Maeda, H. (2000). Generation of lipid peroxyl radicals from edible oils and their biological activities: A need for consideration for anti-radical components and purification processing. BioFactors, 13, 187-193.

Kasaikina, O.T., Kortenska, V.D., Marinova, E.M., Rusina, I.F., Yanishilieva, N.V. (1997). The inhibitory activity of natural phenolic antioxidants in the oxidation of lipid substrates. Russ. Chem. B., 46, 1070-1073.

Kojlo, A.; Michalowski, J. and Wolyniec, E. (2000). Chemiluminescence determination of thioridazine hydrochloride by flow-injection analysis. J. Pharm. Biomed. Anal. 22, 85-91.

Koleva, A., Niederlander, A.G. and van Beek, T.A. (2000). An on-line HPLC method for detection of radical scavenging compounds in complex mixture. Anal. Chem., 72, 2323-2328.

Kondo, K., Kurihara, M., Miyata, N., Suzuki, T. and Toyoda, M. (1999). Scavenging mechanisms of (-)-epigallocatechin gallate and (-)-epicatechin gallate on peroxyl radicals and formation of superoxide during the inhibitory action. Free Rad. Biol. Med., 27, 855-863.

Kricka, L.J. (1994). The clinical and research potential of bioluminescence and chemiluminescence in medicine. In Biolumin. Chemilumin., Proc. Int. Symp., $8^{\text {th }}$ Campell, A.K., Kricka, L.J., Stanley, P.E., Eds.; Wiley: Chistester, U.K.; pp 171-178.

Kruk, I., Michalska, T., Lichszteld, K, Kladna, A. and Aboul-Enein, H. (2000). The Effect of thymol and its derivatives on reactions generating reactive oxygen species. Chemosphere, 41, 1059-1064.

Kubo, H., Saitoh, M., Murase, S., Inomata, T., Yoshimura, Y. and Nakazawa, H. (1999). Chemiluminescence of $\beta$-lactam antibiotics based on the luminol reaction. Anal. Chim. Acta , 389, 89-94.

L'Hostis, E., Michel, Ph.E., Fiaccabrino, G.C., Strike, D.J., de Rooij, N.F. and Koudelka-Hep, M. (2000). Microreactor and electrochemical detectors fabricated using Si and EPON SU-8. Sensors an actuatros-BChemical, 64, 156-162.

Libes, S. M., An Introduction to Marine Biogeochemistry. John Wiley \& Sons, Inc. 1992, pp 3.
Mclntosh, L. J., Trush, M.A. and Troncoso, J.C. (1997). Increased susceptibility of Alzheimer's disease temporal cortex to oxygen free radical-mediated processes. Free Radical Biol. \& Med., 23, 183-190.

Michel, P.E., Fiaccabrino, G.C., de Rooij, N.F. and Koudelka-Hep, M. (1999b). Integrated sensor for continuous flow electrochemiluminescent measurements of codeine with different ruthenium complexes. Anal. Chim. Acta, 392, 95-103.

Michel, P.E., Van der Wal, P.D., Fiaccabrino, G.C., de Rooij, N.F. and Koudelka-Hep, M. (1999a). Reagentless sensor integrating electrodes, photodetector and immobilized co-substrate for electrochemiluminescence based assay. Electroanalysis, 11, 1361-1367.

Miyazawa, T., Kunika, H., Fujimoto, K., Endo, Y., Kaneda, T. (1995). Chemiluminescence detection of mono-hydroperoxy, bis-hydroperoxy, and tris- hydroxperoxy triacylglycerols present in vegetable-oils. Lipids, 30, 1001-1006.

Moure, A. , Cruz, J.M., Franco, D., Dominguez, J,M. , Sineiro, J., Domínguez, H., Nuñez, M.J. and Parajó, J.C. (2001). Natural antioxidants from residual sources. Food Chem., 72, 145-171.

Navas, M.J. and Jiménez, A. (1999). Chemiluminescent methods in alcoholic beverages analysis. J. Agric. Food Chem., 47, 183-189.

Navas, M.J., Jiménez, A.M. and Galán, G. (1997). Air analysis: Determination of nitrogen compounds by chemiluminescence. Atmos. Environm. 31, 3603-3608.

Navas. M.J. and Jiménez, A.M. (1996). Review of chemiluminescent methods in food analysis. Food Chem. 55, 7-15.

Ogawa, A., Arai, H., Tanizawa, H., Miyahara, T. and Toyo'oka, T. (1999). On-line screening method for antioxidants by liquid chromatography with chemiluminescence detection. Anal. Chim. Acta, 383, 221-230.

Okamura, K., Gamo, T., Obata, H., Nakayama, E., Karatani, H. and Nozaki, Y. (1998). Selective and sensitive determination of trace manganese in seawater by flow through technique using luminolhydrogen peroxide chemiluminescence detection. Anal. Chim. Acta , 377, 125-131.

Ouyang, J., Baeyens, W.R.G., Delanghe, J., Van der Weken, G, and Calokerinos, A.C. (1998). Cerium (IV)-based chemiluminescence analysis of hydrochlorothiazide. Talanta, 46, 961-968.

Ouyang, J., Baeyens, W.R.G., Delanghe, J., Van der Weken, G., Van Daele, W., De Keukeleire, D., and García Campaña, A.M. (1999). Chemiluminescence- based liquid chromatographic determination of hydrochlorothiazide and captopril. Anal. Chim. Acta, 386, 257-264.

Palilis, L.P. and Calokerinos, A.C. (2000). Analytical applications of chemiluminogenic reactions. Anal. Chim. Acta 413, 175-186.

Paseková, H. and Polasek, M. (2000). Determination of procaine, benzocaine and tetracaine by sequential injection analysis with permanganate induced chemiluminescence detection. Talanta 52, 67-75.

Pérez-Ruiz, T., Martínez Lozano, C., Baeyens, W.R.G., Sanz, A. and San Miguel, M.T. (1998). Determination of tiopronin in pharmaceutical using a chemiluminescent flow-injection method. J. Pharm. Biomed. Anal., 17, 823-828.

Pérez-Ruiz, T., Martínez Lozano, C., Tomás, V. and Martín, J. (1999a). Flow injection determination of lactate based on a photochemical reaction using photometric and chemiluminescence detection. Analyst, 124, 1517-1521.

Pérez-Ruiz, T., Martínez-Lozano, C., Tomas, V. and Martín, J. (1999b). Flow injection determination of vitamin $\mathrm{K}_{3}$ by a photoinducted chemiluminescent reaction. Analyst 124, 197-201. 
Price, D., Mantoura, R.F.C. and Worsfold,P.J. (1998). Shipboard determination of hydrogen peroxide in the western Mediterranean sea using flow injection with chemiluminescence detection. Anal. Chim. Acta , 371 , 205-215.

Prior, R and Guohua, C. (2000). Analysis of botanical and dietary supplements for antioxidant capacity: a review. J. AOAC Int., 83, 950-956.

Qin, W., Zhang, Z. and Liu, H. (1997). Chemiluminescence flow sensor for the determination of vitamin $\mathrm{B}_{12}$. Anal. Chim. Acta 357, 127-132.

Rizk, M., Belal, F., Ibrahim, F., Ahmed, S. and El-Enany, N. (2000). Spectrofluorimetric analysis of certain 4-quinolones in pharmaceuticals and biological fluids. Pharm. Acta Helv. 74, 371-377.

Robards, K. and Antolovich, M. (1997). Analytical Chemistry of fruit bioflavonoids. A Review. Analyst, 122, 11R-34R.

Robards, K., Prenzler, P.D., Tucker, G., Swatsitang, P. and Glover, W. (1999). Phenolic compounds and their role in oxidative processes in fruits. Food Chem., 66, 401-436.

Roda A., Pasini, P., Guardini, M., Baraldini, M. and Mirasoli, M. (2000). Bio- and Chemiluminescence in bioanalysis. FreseniusJ. Anal. Chem. 366, 752-759.

Sakiara, K.A., Pezza, L., Melios, C.B., Pezza, H.R. and De Moraes, M. (1999). Spectrophotometric determination of dipyrone in pharmaceutical preparations by using chromotropic acid. Farmaco, 54, 629-635.

Savuck, S.A., Rudenko, B.A. , Brodskii, E.S. and Soifer, V.S. (1995). Application of gas chromatography with open tubular columns and chemiluminescent detection to the determination of sulfur-containing substances in oil pollution of sea water. J. Anal. Chem. (Trans of Zh. Anal. Khim.) 50, 1081-1087. (C.A. 124:96900, 1997)

Sawa, T., Akaike, T., Kida, K., Fukushima, Y., Takagi, K., Maeda, H. (1998). Lipid peroxyl radicals from oxidized and heme-iron: Implication of a high-fat diet in colon carcinogenesis. Cancer Epidem., Biomar., 7, 1007-1012.

Schmidt, B. (1999). Light Minded: Instruments for chemiluminescence and fluorescence measurements. The Scientist 13, (http://www.the-scientist.com/yr1999/. may/profile1990510.html).

Shipboards techniques based on flow injection analysis for measuring dissolved $\mathrm{Fe}, \mathrm{Mn}$ and $\mathrm{Al}$ in seawater. $J$. Environ. Monit., 2 ,496-502.

Smith, M.A., Rottkamp, C.A., Nunomura, A., Raina, A.K. and Perry, G. (2000). Oxidative stress in Alzheimer's disease. Biochim. Biophys. Acta, 1502, 139-144.

Sugawara, T., Miyazawa, T. (1999). Microanálisis of triacylglycerol hydroperoxides by chemiluminescenceHPLC assay. Nihon Yukagakkaishi, 48, 1391-1395. (C.A. 132:121612, 2000)

Sultan, S.M., Abdennabi, A.M.S. and Almuaibed, A.M. (1999). Chemiluminescence method for the assay of perphenazine in drug formulation using permanganate in sulphuric acid with flow injection technique and a chemometrical optimization approach. Talanta, 49, 1051-1057.

Suzuki, N., Hatate, H., Mizumoto, I. and Nomoto, T. (1998). Antioxidative activity against active oxygen species. Recent res. Devel. Agricultural \& Biological Chem. 2, 283-292.

Thanasoulias, N. K., Vlessidis, A. and Nicholaos, P.E. (1999). Influence of oxidant-species scavengers on the chemiluminescence $(\mathrm{CL})$ emission generated during the oxidation of pyrogallol by hydrogen peroxide. Anal. Chim. Acta, 401, 197-207.
Townshend, A. (1990). Solution chemiluminescence-some recent analytical developments. Analyst 115, 495-500.

Travis, J.C., Kramer, G.W., Smith and M.V., Choquette, S.J. (1999). Challenges in providing standard reference materials for chemical and pharmaceutical process analysis. Anal. Chim. Acta 380, 115-126.

Van Fleet-Stalder, V. and Chasteen, T.G. Using Fluorine-Induced Chemiluminescence to Detect Organo-Metalloids in the Headspace of Phototrophic Bacterial Cultures Amended with Selenium and Tellurium. http:// www. shsu.edu/ chmtgc/ publications/JPP/Chasteen.htm

Wang, L.H. (2000). Simultaneous determination of retinal, retinol and retinoic acid (all-trans and 13-cis) in cosmetics and pharmaceuticals at electrodeposited metal electrodes. Anal. Chim. Acta 415, 193-2000.

Wheatley, R.A. Lipid chemiluminescence, in Hamilton and Cast's book, "Spectral Properties of lipids" . Sheffield Academic Press, 1999, pp 49-96.

Yasei, P.M., Yang, G.C., Warner, C.R., Daniels, D.H. and $\mathrm{Ku}, \mathrm{Y}$. (1996). Singlet oxygen oxidation of lipids resulting from photochemical sensitizers in the presence of antioxidants. JAOCS, 73, 1177-1181.

Yildiz, G. and Demiryürek, T. (1998). Ferrous iron-induced luminol chemiluminescence: A method for hydroxyl radical study. J. Pharmacol. Toxicol. Method, 39, 179-184.

Yun, J.H., Han, I.S., Chang, L.C., Ramamurthy, N., Meyerhoff, M.E. and Yang, V.C. (1999). Electrochemical sensors for polyionic macromolecules: development and applications in pharmaceutical research. Pharm. Sci. Technol. Today 2, 102-110.

Zamzow, H., Coale, K.H., Johnson, K.S. and Sakamoto, C.M. (1998). Determination of copper complexation in seawater using flow injection analysis with chemiluminescence detection. Anal. Chim. Acta, 377, 133-134.

Zhang, C., Huang, J. and Zhang, Z. (1998b). Flow injection chemiluminescence determination of cathecholamines with electrogenerated hypochlorite. Anal. Chim. Acta 374, 105-110.

Zhang, C., Huang, J., Feng, M. and Zhang, Z. (1998a). Flow injection chemiluminescence determination of etamsylate with electrogenerated hypochlorite. Anal. Lett., 31, 1917-1928.

Zhang, X.R., Baeyens, W.R.G., Van der Weken, G., Calokerinos, A.C., and Nakashima, K. (1995). Chemiluminescence determination of captopril based on a Rhodamine B sensitized cerium(IV) method. Anal. Chim. Acta 303, 121-125.

Zhang, Z. and Qin, W. (1996). Chemiluminescence flow sensor for the determination of ascorbic acid with immobilized reagents. Talanta 43, 119-124.

Zhang, Z.D., Baeyens, W.R.G., Zhang, X.R. and Van der Weken, G. (1996). Chemiluminescence determination of penicillamine via flow injection applying a quinine-cerium(IV) system. Analyst 121, 1569-1572.

Zhao, Y., Baeyens, W.R.G., Zhang, X., Calokerinos, A.C., Nakashima, K. and Van Der Weken, G. (1997). Chemiluminescence determination of tiopronin by flow injection analysis based on cerium(IV) oxidation sensitized by quinine. Analyst 122, 103-106.

Zheng, X. and Zhang, Z. (1999). Flow-injection chemiluminescence determination of isoniazid using on-line electrogenerated $\mathrm{BrO}^{-}$as an oxidant. Analyst, 124, 763-766.

Zui, O. V. and J. W. Birks (2000). Trace analysis of phosphorus in water by sorption preconcentration and luminol chemiluminescence. Anal. Chem., 72, 1699-1703 